\title{
Application of Ultimum Remedium Principles in Progressive Law Perspective
}

\author{
Hamidah Abdurrachman ${ }^{1, *}$, Achmad Irwan Hamzani ${ }^{1}$, Fajar Ari Sudewo ${ }^{1}$, Havis Aravik ${ }^{2}$ and \\ Nur Khasanah ${ }^{3}$
}

${ }^{1}$ Universitas Pancasakti Tegal, 52121, Indoensia

${ }^{2}$ STEBIS-IGM, Palembang, 30129, Indonesia

${ }^{3}$ IAIN Pekalongan, 51141, Indonesia

\begin{abstract}
Ultimum remedium is one of the principles contained in Indonesian criminal law which says that criminal law should be made a final effort in the case of law enforcement. However, law enforcement through the criminal justice system is currently still dominated by the positivism mindset, a way of (criminal) law enforcement which is only based on laws and regulations. In many cases, Criminal Law is used as the only way of order. The purpose of this research is to describe the concept of Ultimum remedium in criminal law, criminal law enforcement practices in Indonesia, and criminal law enforcement concepts in the progressive law paradigm. This research used a philosophical approach discussing law enforcement idealism in the future. The data used were the qualitatively analyzed secondary data. The research results showed that the Ultimum remedium principle has not been completely implemented in law enforcement. Consequently, the burden for crime settlements got bigger and made the law enforcers busier. The Ultimum remedium principle is supported by various considering bases or grounds from the constitutional law aspect, political science, criminal law, and humanism consideration or human rights. Law enforcement in Indonesia was viewed as stagnant and discriminative law enforcement. It was illustrated as a spider web that can only trap the weak but will be easily torn by the rich and strong. Factors inhibiting law enforcement in Indonesia include weak political will and political action of the state leaders to make law as the commander. The regulations and laws reflect the political interests of authorities more than those of the society. Thus, criminal law enforcement is greatly necessary for the progressive law paradigm. Progressivity is greatly required in law enforcement. Progressive law departs from the humanistic perspective. Thinking progressively means having the courage to get out from the law absolutism thinking mainstream and positioning law in the relative position located in the entire humanistic problems.
\end{abstract}

Keyword: Ultimum remedium, law enforcement, progressive.

\section{INTRODUCTION}

In general, it is stated that Criminal Law is used to deal with crime and prevent crime by posing strict and strong sanctions as protection for law interests, namely people (dignity, soul, property, body, and others), society, and state (Rahmawati, 2013: 39). In other words, criminal law has the meaning of preventing the less healthy social symptoms besides medicating those who have already made non-commendable deeds to regulate and limit human behaviors in eliminating the violations to the public interests (Priyono, Agus Puji, 2019).

Criminal law was only utilized when the other sanctions have been implemented and follow the violation levels which are relatively big made by the society or resulting in public anxiety (Firdaus et al., 2020). Criminal law or straftrecht in the Dutch language is part of the whole law regulating violation and crime of public interest (Kukuh, 2015: 210). The other definition according to Moelyatno is part of whole prevailing laws throughout all countries, by establishing basic rules to

*Address correspondence to this author at the Universitas Pancasakti Tegal, 52121, Indoensia; E-mail: h-abdurrachman@upstegal.ac.id

E-ISSN: 1929-4409/21 determine which acts are not allowed, prohibited along with threats or sanction in the form of certain punishments for anyone violating the prohibitions and determining when and what matters to they who violate it may be imposed/punished according to what is threatened and also determining with what method such punishment may be enforced in case someone is suspected to have violated the prohibitions (Ariyanti, 2019).

Law principle is something abstract and underlying a concrete regulation and law implementation (Anwar \& Wijaya, 2020). The criminal law essential principles include Primum remedium and Ultimum remedium. Primum remedium can be said as the only thing which can be made except with the implementation of the related criminal law, no other alternative as the principle or foundation to enforce a law. Meanwhile, Ultimum remedium is the opposite of primum remedium, in which there is an alternative settlement besides implementing a criminal law rule.

The important principle in criminal law is Primum remedium and Ultimum remedium. Primum remedium may be stated as the only thing that can be performed except by applying the criminal law, no other alternative 
as the basis or foundation to enforce a law. Meanwhile, Ultimum remedium is the opposite of primum remedium, which means there is another alternative settlement besides applying a rule of criminal law.

Ultimum remedium is the last resort used when sanction or effort of any other law branch does not work or is deemed not to work. Therefore, its use must be limited. In case of any other way, criminal law should not be used (Soedarto: 2013, 20). This characteristic of Ultimum remedium also differentiates criminal law from other sub-law fields since other sublaws, such as civil law, constitutional law, and state administrative law in their use are not Ultimum remedium like criminal law, but primum remedium, which may be made the main or first resort of its use (Resort, 2020).

Indonesian judicial agency is also very poor, particularly one conducted by law enforcement elements from police, public prosecutor, judge to Correctional Institution (LP) officer (Sunaryo, 2005: 56). Law enforcement through the criminal justice system is currently still dominated by the positivism mindset, a way of (criminal) law enforcement which is only based on laws and regulations. Such way views legal issues like white and black, while the law is not merely a space that is sterile from non-legal concepts. Law must also be viewed from a social perspective, behavior which may be accepted by and for all people therein (Ali, 2007: 210). Considering that criminal law is a law used as the "last resort", which must be used carefully. Criminal law with a strict sanction is stated to have a subsidiary function, which means that if another legal function is lacking, criminal law is then used, and it is often said that criminal law is Ultimum remedium or the last resort. However, in the current condition, and as may be observed in the media's report, criminal law is no longer the last effort of settlement of a dispute or Ultimum remedium. Criminal law is the prioritized effort of settlement or primum remedium.

Police that is the first officer to deal with crime shows law enforcement as the goal. The data below show Police's work as Law Enforcer: The Indonesian National Police's Criminal Investigation Division records 104 people suspected of distributing hoaxes regarding Covid-19. 17 people are detained while the other 87 people are not detained (News Detik.com, 24 November 2020). Even in dealing with violation of Health Protocol in the prevention of Covid-19 transmission, the National Police Headquarters opens the possibility to imprison those who violate the health protocol (Tempo.com, 13 September 2020). The Indonesian National Police's data record that in 2018 there are 226,128 cases while in 2019 there are 202,292 cases handled (rri.co.id, 29 Des 2019 13:32).

This article will discuss the Ultimum remedium concept in criminal law, criminal law enforcement practices in Indonesia as the implementation of Ultimum remedium. The criminal law enforcement concepts are then formulated in the progressive law paradigm.

\section{LITERATURE REVIEW}

\section{Criminal Law Concept}

Until now, there is no certain definition of law. In other words, there is no definition of law that is made the standard to understand the meaning and concept of law (Darwis, 2003: 6). Notohamidjojo defines law as the whole written and non-written regulations which are usually compelling, for human conduct in state-society (and between countries), leading to justice, to realize peace order, aiming at humanizing humans in the society (Notohamidjojo, 2011: 121). Meanwhile, according to Soedarto, punishment is suffering deliberately charged to a person who commits some act that meets certain requirements (Muladi and Arief, 2005: 2).

S. Kartanegara defined criminal law as the entire rules of the positive law containing prohibitions and obligations regulated by the state or authorities to determine the criminal rules. Those prohibitions and obligations are followed by penalties to those violating the rules. Criminal law is not a law containing new norms, but as one providing sanctions asserting and strengthening the rules contained in the other legislations to obey (Wibawa, et al., 2018). W.L.G Lemaire defines criminal law as consisting of norms containing obligations and prohibitions (by lawmaker) associated with a sanction in the form of punishment, which is special suffering. Therefore, we may also state that criminal law is a system of norms that determines which acts (committing something or not committing something where there is an obligation to do something) and in which conditions a punishment may be imposed to for such acts (Azisa, 2016).

Therefore, criminal law is defined as a provision of law determining acts that are prohibited/taboo to be done and threatened sanction for any violation of such prohibition. Many experts argue that Criminal Law 
occupies a special place in the law system since criminal law does not occupy a special norm, but strengthens norms in another field of law by determining threatened sanction for violation $f$ norms in the other law field (Zaidan, 2015: 3). The definition above conforms to the criminal law principle contained in Article 1 paragraph 1 Criminal Code that criminal law is derived from written regulation (legislation in a broad sense), which is also called legality. The application of legality principle is protective to criminal law which protects the people in the implementation of the government's unlimited power.

The characteristic of law is compelling along with threat and sanction. However, the law is not forced to justify something wrong or force those who have no position and money. For regulations of social life to truly be complied with and obeyed to become a legal principle, the society regulations must be accompanied by a compelling element. Therefore, the law is regulating and compelling every person to comply with the order in the community and pose strict sanction (in the form of punishment) to anyone who does not comply with it (Suharto and Efendi, 2010).

The existence of regulations that regulate and compel society members to comply with and obey them will lead to balance and peace in their life. Criminal law experts state that the objective of criminal law is: First, to scare people so that they will not commit a crime (preventive). Second, to educate or correct those who have indicated that they like to commit a crime to have good character (repressive) (Prodjodikoro, 2003: 20).

The objective of criminal law is divided into 2 (two), namely (Teguh Prasetyo, 2010,7): First, the objective of criminal law as sanction law: this objective of conceptual or philosophical, aiming to present the base of criminal sanction. The type and form of criminal sanction also serve as the parameter of criminal violation settlement. This objective is usually nonwritten in criminal law articles but may be read from all provisions of criminal law or in a general explanatory note. Second, the objective of rendering criminal sanction to those violating criminal law: this objective is pragmatic with clear and concrete size relevantly to the problem arising from the violation of criminal law and those violating criminal law. This objective is the realization of the first objective.

\section{Ultimum Remedium Principle}

Ultimum remedium is one of the principles contained in Indonesian criminal law which says that criminal law should be made a final effort in the case of law enforcement (Kartanto, et al., 2020, Subyakto, 2015). Since the implementation of the law, in principle, is greatly selective, unless the law is carelessly implemented (Vollaard, 2013). This means that if a case may be settled through another path (kinship, negotiation, mediation, civil, or administrative law) that path should be first taken. The character of criminal sanction as the final resort or Ultimum remedium compared to civil sanction or administrative sanction has strict sanction.

Topo Santoso states that one thing to differentiate criminal law from any other law, both public and private laws, is sanction. Criminal sanctions may be in the form of imprisonment, making the convict to be alienated and separated from family and society. The cruelest sanction is the death penalty, making the convict be separated from his life. The Ultimum remedium principle is in the middle of moral and law, and Ultimum remedium is the principle of all legislation processes. Thus, how to reject criminalization or negotiation, then Ultimum remedium is the standard, not when we enforce the law when there is existing law, article, then police or public prosecutor certainly cannot use this principle. Ultimum remedium is a common term that is then usually used or associated with the law. This term describes a legal characteristic, as the last choice or instrument is well known in criminal law (Nur, 2013: 40).

According to W. Prodjodikoro (2003), the norms or principles in constitutional law and state administrative law must first be responded to with administrative sanction. Similarly, norms in civil law should first be responded to with civil sanction. However, when administrative sanction and civil sanction are not sufficient to reach the objective of aligning social balance, the criminal sanction is then used as the last resort or Ultimum remedium. This way, the characteristic of criminal sanction is as the last resort Ultimum remedium, compared to civil or administrative sanction. This characteristic has led to the tendency to reduce criminal sanctions. Thus, we may find here that Ultimum remedium is a term that describes a characteristic of criminal sanction. It is the introduction of criminal sanction in the form of suffering which makes criminal law used as the last resort (Ultimum remedium) to correct human behavior, particularly criminals, and pose psychological pressure for others not to commit a crime (Bemmelen, 1987: 16). Sudikno Mertokusumo defines Ultimum remedium as the last instrument (Mertokosumo, 2006, 128), which means 
that criminal sanction may be used when other sanctions cannot cause the deterrent effect to the committer. The provisions of criminal sanction in a Law are taken as the last sanction after administrative and civil sanctions cannot be used anymore. This effort is intended that in the relatively long criminal law process, the victim and perpetrator will receive justice and certainty of law.

Van de Bunt states that criminal law as Ultimum remedium has three meanings (Mas, 2017: 267): the application of criminal law only to the person who violates the law is ethically very heavy; criminal law as Ultimum remedium since the sanction of criminal law is heavier and harsher than the sanction of other law fields, and even with side effects, thus it should be applied when sanction of other law field is not capable of settling the law violation (last resort); criminal law as Ultimum remedium since it is the administrative officer who is the first to know any violation. It is them prioritized to take measures and acts instead of criminal law enforcer.

\section{Law Enforcement Concept}

Law enforcement is an effort to deal with crime rationally, fulfill the sense of justice, and is useful. In dealing with a crime on various mediums as reaction which may be rendered to the perpetrator, in the form of criminal medium and non-criminal law, which may be integrated. When a criminal medium is called to deal with crime, criminal law politics will be implemented, which is to hold voting to reach the result of criminal legislation which conforms to the condition and situation of a time and for future time (Arief, 2002: 109).

Indonesia is a nation of law (recht staats), thus every person committing a crime must be held accountable for his actions through a legal process. Law enforcement bears the meaning that crime is an act prohibited by a rule of law, in which the prohibition is accompanied by a threat (sanction) in the form of certain punishment as his accountability. in his case, there is a relationship with the legality principle, thus there is no act which may be punished except it has been set forth by the law, thus anyone violates the prohibition and the prohibition has been outlined in the law, any committer of it may be imposed with sanction or punishment, while the threatened punishment is addressed to anyone who causes such occurrence, and there is a close relationship (Hamzah, 2001: 15).

Meanwhile, law enforcement, as formulated by Abdul Kadir Muhamad, is the effort to implement the law appropriately, supervise its implementation so there is no violation, and in case of violation, to recover the violated law to be re-enforced. The definition shows that law enforcement lies in the activities performed by a law enforcement officer. Law enforcer's activity lies in earnest effort to realize juridical norms. Realizing a norm means applying the existing rule to catch anyone who violates the law. Law violation serves as the keyword to determine whether or not law enforcement is a success (Sunardi, Tanuwijaya, Wahid, 2005).

\section{RESEARCH METHOD}

This research used a philosophical approach. A philosophical approach in legal research is discussing law in ideal sides. This research used a philosophical approach because formulating a law at the ideal level (ius constituendum), in the form of ideas in implementing the Ultimum remedium principle and progressive law paradigm in imposing penalties. The data sources used in this research were the secondary data indirectly obtained from or provided by the other parties. The secondary data used were legal documents utilized as the main references to discuss the Ultimum remedium principles, criminal law enforcement in Indonesia, and progressive law paradigm. The data collection technique used in this research was tracing through both offline and online. Library tracing conducted offline was related to the activities made by searching the reference sources from the data storages. Meanwhile, the tracing conducted online was related to the activities searching reference sources in the cyber world through internet networks. Tracing references were conventionally made by searching the reference materials from libraries, private book and journal collections, book purchases, and attending scientific (seminar) activities. Online tracing was also made by searching references through the internet. The data analysis method was qualitative. Qualitative data analysis is a process of organizing and arranging the data in order based on patterns, categories, and basic explanation units that the themes presented are in the form of narrations (Hamzani, 2020). This research used a qualitative data analysis since the data were presented in narrativedescriptive, not in the form of numbers or numeric.

\section{DISCUSSION}

\section{The Principle of Ultimum Remedium in Criminal Law}

Law enforcement through the criminal justice system is currently still dominated by the positivism 
mindset, a way of (criminal) law enforcement which is only based on laws and regulations. Such way views the legal issue as white and black, while the law is not merely a space that is sterile from non-legal concepts. When the law is viewed from a social perspective, behavior may be accepted by and for all people therein, considering that criminal law is the law which is used as the "last resort", which should be used carefully since it contains heavy sanction for the perpetrator. The prevailing criminal law should reflect the government's ideology of, concern about and attachment to its people, not merely law that the people desire to rule them.

In criminal law, the Ultimum remedium proposition is needed to consider first the use of other sanctions before rendering a strict and strong criminal sanction, if another law function is lacking, criminal law is used then. About the characteristics of criminal law in the context of Ultimum remedium that criminal law enforcement with strict and strong must be attempted to reduce perpetrator's suffering. The application of Ultimum remedium in rendering criminal sanction by the judge may accommodate the perpetrator's interest, and any activity referring to the application of imprisonment as the last resort (Ultimum remedium) greatly supports the perpetrator, since before strict criminal sanction is rendered, the use of other sanction such as administrative and civil sanction is prioritized, thus when the function of the law sanctions is lacking, criminal sanction is then imposed. However, considering the other concern through Van Bemmelen, the implementation of this Ultimum remedium should be meant as "effort" (middel), not an instrument to recover injustice or recover a loss, but an effort to recover non-peaceful condition in the society, that when not made for that injustice, it may lead to vigilantism.

Concerning Hoenagels's idea, the importance of considering various factors of criminalization is reemphasized to keep the Ultimum remedium proposition and there will be no overcriminalization, such as (Garnasih, LBH Pers): a. Do not use criminal law emotionally; b. Do not use criminal law to punish an act of which victim or loss is unclear; c. Do not use criminal law, if the loss caused by punishing will be bigger than the loss caused by the crime that will be formulated; $d$. Do not use criminal law when it is not supported by society strongly; e. Do not use criminal law when its use is expected to be ineffective; $f$. Criminal law in certain matters should specifically consider the priority scale of setting interest; g. Criminal law as a repressive medium should be used simultaneously with the preventive medium. About Ultimum remedium implementation, law enforcement officer at the frontline, namely the police, serves to determine the reported case (Indrawati, Benedito,2018: 17). The police often just receive a report and process it through criminal law without considering social aspects or another aspect. It seems as if the crime is a "fixed price", which cannot be covered up or settled through any other way, such as administrative way.

The Ultimum remidium principle can also be found in other countries, the United States and Beijing. Criminal Law as The Last Resort is a principle that is generally inherent in criminal law. The existence of the Ultimum remedium doctrine is acknowledged and accepted in many countries, and even in countries with a common law system that is based more on unwritten rule of law which develops through a court decision. However, there is no understanding that Ultimum remedium is a principle with a juridical basis. Although some scholars still challenge the existence of this doctrine from its normative aspect, there is a basis of thinking, consideration, or support to acknowledge the existence of this doctrine in various studies.

"We do not have much basis to decide how applications of the last resort principle would affect our drug policy. Although the details would differ from case to case, I suspect that many of these same problems would reappear if the last resort principle were applied elsewhere. These tremendous uncertainties provide a concrete reason to doubt that the last resort principle would have a substantial impact on our system of criminal justice. None of these unresolved issues should persuade us that the last resort principle should not be included in our theory of criminalization. But they reinforce what I take to be Jareborg's pessimistic conclusion: the last resort principle would not be especially helpful in retarding the phenomenon of overcriminalization." (Ali, Hukum, \& Grafika, 2009)

In Beijing, The Last Resort principle in the Beijing Rules is found in Rule 13.1 as follows. "The placement of a juvenile in an institution shall always be a disposition of last resort and for the minimum necessary period. Child imprisonment is the last resort to prevent a child from the jail's adverse influence on the child's growth and development. Rule 13.1 encourages new and innovative measures to avoid detaining children with law issues (Syachdin, 2016: 210). 


\section{Criminal Law Enforcement in Indonesia}

There must be the will in law enforcement issue for the law to be enforced, thus the values of law instrument will be realized (Marilang, 2017: 316). The ideas contained in law enforcement cannot be truly reached, since the law is used as an act to protect some people or a certain group. Law enforcement is a process where efforts are made to enforce legal norms for real as the code of conduct in law relations in the life of the people and of the state. From the subject's perspective, law enforcement may be performed by a broad subject and may also be defined as an effort of law enforcement by the subject in a limited or narrow sense. In this case, the definition also covers broad and narrow sense. In a broad sense, law enforcement also covers justice values contained therein, the text of formal rules, and justice values existing in the community. However, in the narrow sense, law enforcement is only about formal and written regulations. Therefore, "law enforcement is translated into 'law enforcement in a broad sense and 'regulations enforcement in a narrow sense in the Indonesian language.

Law enforcement is the effort made to make law, both in the narrow formal sense and broad material sense, as the code of conduct in every legal action, both by the concerned legal subjects and the law enforcement officers officially given with duties and authorities by the law to ensure the function of prevailing legal norms in the life of the people and of the state. From the broad definition, the boundaries of discussion on law enforcement may be determined, whether we will discuss the whole aspects and dimensions of law enforcement, either from subject or object perspective or we just limit on certain matters, for example, only reviewing its subjective aspects. Enforcement issue is not an easy issue, since the legal system is very complex, and also because of the complicated relations between the legal system and the society's social, political, economic, and cultural systems. As a process, law enforcement is a variable with correlation with other factors.

On the other hand, law enforcement in Indonesia is highlighted as stagnant law enforcement and even if it is enforced, it is made discriminatively. Misappropriation practices in the law enforcement process, such as judicial mafia, discriminative judicial process, judge decision trade or collusion by Police, Judge, Advocate and Public prosecutor in judicial process engineering, is a daily reality that we may find in law enforcement. Such a "dirty" law enforcement implementation makes the law in this country as described by a great Greece philosopher Plato (427$347 \mathrm{BC}$ ) that laws are spider webs; they hold the weak and delicate who are caught in their meshes but are torn in pieces by the rich and powerful. Law enforcement officer covers the definition of law enforcement institution and officer. In a narrow sense, the law enforcement officer is involved in the law enforcement process, from witnesses, police, attorney, public prosecutor, judge, and warden. The concerned officer and apparatus also cover the concerned parties with duties or roles related to reporting or complaint, preliminary investigation, full investigation, prosecution, evidencing, sentencing and sanctioning, and resocialization of the convict.

There are at least seven factors that inhibit law enforcement in Indonesia: First, state leaders' weak political will and political action to make the law the commander of governance. In other words, the supremacy of law is still limited to political jargon and rhetoric spread during the campaign. Second, the existing laws and regulations reflect the ruler's political interest more than that of the people. Third, low moral integrity, credibility, professionalism, and legal awareness of law enforcement officers (Judge, Public Prosecutor, Police, and Advocate) in enforcing the law. Fourth, minimum facilities and infrastructure may support a smooth law enforcement process. Fifth, society's low level of legal awareness and culture and lack of respect to the law. Sixth, the law enforcement paradigm is still positivist-legalistic which prioritizes achieved formal justice to substantial justice. Seventh, the policy made by the stakeholders in solving law enforcement issues is still partial, incremental, noncomprehensive, and systematic (Faizal, 2007).

Law enforcement is a process of upholding or functioning legal norms concretely as a guideline of behavior in traffic or legal relations in public and state life. Law enforcement can be reviewed from 2 (two) aspects, namely from the angle of the subject and its object. Judging from the object, the concept of law enforcement narrowly in terms of law enforcement concerns the enforcement of formal and written regulations only. Law enforcement in this narrow sense can also be termed 'law enforcement. More deeply related to the law in the narrow sense is also known the term 'the rule by law', the law is merely a tool of power. The element to be achieved in this case is legal certainty (rechtssicherheit). 
Law enforcement covers up to the values of justice contained in the sound of formal rules as well as the values of justice that live in society. This is similar to the English terms 'law enforcement and 'the rule of law', which means governance by law, but not only in a formal sense but also includes the values of justice contained therein. The element of justice (gerechtigkeit) speaks of the sense that exists in each individual as well as in the community. The creation of justice that adheres to the sense of community, by itself created a sense of security and peace (Wisnubroto, 2017). With such a sense of security and peace fulfilled, there is no reason for a person to commit an act that causes chaos.

\section{Application of Ultimum Remedium Principles in a Progressive Law Perspective}

The principle of ultimum remedium is necessary to first consider the use of other sanctions before the criminal is imposed. If other legal functions are lacking then-new criminal law is used. Ultimum remedium in a criminal prosecution is supported by various basic considerations or evidence from aspects of state law, political science, criminal law, and humanism considerations. The use of the principle of ultimum remedium is based on the view of humanity, that human beings are good, have compassion and concern for others as an important capital to build a legal life in society.

Since modern law is increasingly based on the dimensions of the form that makes it formal and procedural, then since then there has also been a difference between formal justice or justice according to the law on the one hand and true justice or substantial justice on the other. With these two dimensions of justice, it can be seen that in practice the law can be used to pervert substantial justice. The use of such a law does not mean to violate the law but merely indicates that it can be used for purposes other than achieving justice (Adji, 2011).

If the law becomes as bad as it has been in Indonesia, the problem is with the law enforcement officials, namely police, prosecutors, judges, and advocates. Not entirely to blame and accused as the only defendant for the destruction of legal authority in Indonesia. All legal entities and communities, especially law enforcement officials must have and the concept that the law is not a finished product when enacted, or the law is not completed when it is listed as a neat and good sentence in the State Gazette (Adji,
2011). The law will be detached from the intelligence (thinking) as felt by legal scientists in Indonesia, who are always imprisoned by modern law through the power of the state is very hegemonic, so that everything in the sphere of state power should be labeled state, state law, state judiciary, state police, state judges and so on.

Think progressively, be bold out of mainstream legal absolutism thinking, then put the law in a relative position. The law must be placed in the whole matter of humanity. Working based on a legal determinant mindset is necessary. But that is not an absolute thing to do when jurists are dealing with a problem that if using modern legal logic will hurt the position of humanity and truth. Working based on a progressive legal mindset, certainly different from the positivitypractical legal paradigm because seeing the main factor in the law is man himself. Instead, the positive legal paradigm believes in the truth of the law above man. Human beings can be marginalized as long as the law remains upright. On the contrary, progressive legal paradigms think that the law can be marginalized to support the existentialism of humanity, truth, and justice (Rahardjo, 2007)

Law enforcement is very fundamental in achieving the goal of a peaceful and prosperous Indonesia. The achievement of this goal is closely related to the significance of law enforcement itself. The important meaning that becomes the core in law enforcement conceptually lies in the activities of harmonizing the relationship of values described in the rules that exist in society to maintain and maintain order. Law enforcement is the process of applying existing values and rules and living in the community (Wantu, 2012).

There are several indications to support the phenomenon, among others law enforcement solely prioritizes the element of legal certainty by ignoring the sense of justice of the community. The worldview of law enforcement generally believes that positive law (legislation) is a source of law that is plenary and should be executed as it is (textual). The legislation is a product of politics and politics is interest.

There is no lasting law, because it is a definite formulation, while it has to deal with an ever-changing life. The laws attached to the formulation of the words will always be left behind from the changes that occur in society, which it must control or control (Suhardin, 2009). An essential problem in law enforcement in Indonesia is the factors of law enforcement agencies 
and apparatus. To lay the foundation of law enforcement, the main pillar is law enforcement that can carry out its duties well. It's the same with law enforcement. If law enforcement has not been able to do its job properly then any talk of justice in law enforcement will be nonsense (as long as the dirty broom is not cleaned, any talk of justice will be empty). To carry out good law enforcement, it is expected that law enforcement officials are not just puppets of the law, which implements the provisions of the law normatively only, but it takes innovative and creative thinking by law enforcement officials (Yadyn, et al., 2010).

With the paradigm as a world view, general perspective, or way of breaking down the complexity, it will be obtained a correlation between the paradigm and the legal culture created in society. Paradigm as a world view, general perspective, or way of breaking down the complexity of the law will affect the formation of legal culture that exists in society, namely values in the form of opinions, beliefs, and other ways of thinking, and ways of acting, both from law enforcement and citizens, about the law and various phenomena related to the law. Correlation between paradigm and culture of law also means to provide an understanding that the element of problem-solving (puzzle solving) in the paradigm can also provide problem-solving (solution) to problems in law, especially law enforcement (Wisnubroto, 2017).

The deterioration in law enforcement in Indonesia is predominantly caused by two factors, namely corrupt law enforcement behavior and the mindset of law enforcement officials who are very confined to the legalistic-positivistic mind. The law enforcement that was devastated ultimately did not get a place in the hearts of the community because it did not provide answers to the needs of justice law. The phenomenon of vigilantism in the community can be used as an indication of the weakening of public confidence in the legal mechanisms.

There is a tendency for legal activities in a society characterized by the increasing use of legal resources and the resolution of problems with the law. Increasing public legal awareness is inversely proportional to the process of solving legal problems.

Not always the law is positioned as a counterbalance to the interests of society because the law tends to accommodate the interests of certain elites. Indications when law enforcement puts too much emphasis on aspects of legal certainty by ignoring justice and legal benefits for the community. The adagio of justice has changed with the development of a century of modern nationalism that prioritizes reasoning rarely to satisfy the human mind about the meaning and meaning of justice in the rhythm of legal motion in society.

The law in its implementation must be fair, but what often happens is precisely injustice. Law enforcement officials are not yet fully aware of this. The law enforcement process is far from a sense of community justice. But the nature of the law is justice itself.

Justice in law is the right of every citizen to be guaranteed and protected by the state. Everyone is entitled to recognition, guarantee, protection, and fair legal treatment and obtain legal certainty and equal treatment before the law. Legal justice that appears more legal-formal, justice based on written texts contained in the law (rule-bound).

Seeing the problematics of law enforcement that occurs in Indonesia progressive legal ideas are increasingly relevant. The idea of progressive law emphasizes the interpretation of the law as an effort to explore the values that live in a society to create a fair verdict. This thinking is by the legal needs of the Indonesian people, especially for small people who do not have an economic, political, or social bargaining position that will affect the law. Progressive law also offers a new way of applying the law by involving the conscience (Rahardjo, 2009).

Law enforcement should be able to feel the moral message contained in a piece of legislation. There is no lasting law, because it is a definite formulation, while it has to deal with an ever-changing life. Laws fixated on the formulation of words will lag behind the changes that occur in society, which must instead be controlled or controlled.

Progressive law enforcement by exercising the law is not just a black-and-white word of the rule (according to the letter). It takes a deeper understanding (to very meaning) and the spirit of the law is held. Law enforcement simply has intellectual intelligence, but with spiritual intelligence. In other words, law enforcement must be done with determination, empathy, dedication, commitment to the suffering of the nation and accompanied by the courage to find another way than usual.

The essence of progressive law lies in progressive thinking and acting that frees it from the shackles of the 
text of legal documents. The law is not for the text of the law, but the happiness and welfare of man. Legal thinking needs to return to its basic philosophy of law for man, not the other way around for law (Raharjdo, 2009). The law is not an absolute and final institution, but rather an amoral, impersonated institution, and therefore highly determined by its ability to serve people. Law is an institution that aims to lead people to a just, prosperous life and make people happy. Progressive law does not think according to the legal way but according to the reasonable way. In the event of a stalemate, progressive laws will do creative alternative ways, on top of running creative alternative ways "to the letter". If progressive law is used as a paradigm by law enforcement in Indonesia, then the principle of ultimum remidum will be very easy to apply. The legal action will take into account the benefits and fairness aspects, rather than just complying with the provisions.

\section{CONCLUSION}

Based on the above discussion, it can be concluded that ultimum remedium is another sanction before a harsh and sharp criminal is imposed. The application of ultimum remedium can accommodate the interests of perpetrators of criminal acts. Criminalization refers to the application of the principle of imprisonment as a last resort. Administrative sanctions and civil sanctions can take precedence. The application of ultimum remedium is not a tool to restore injustice or to recover losses, but rather an attempt to restore an unearthly situation in society. If something is not done to the injustice, it can lead to vigilantism. Law enforcement in Indonesia is highlighted as stagnant and discriminatory law enforcement. Misappropriation practices such as mafia judiciary, buying and selling judge's verdicts, or law enforcement collusion are realities that can be found in law enforcement. It is like a cobweb that is only able to ensnare the weak but will be torn if it entangles the rich and strong. Factors that hinder law enforcement in Indonesia include the weakness of political will and political action of the country's leaders to become law as commander in chief. The paradigm of law enforcement is still positive-legalistic that prioritizes the achievement of formal justice rather than substantial justice is also a deterrent factor. Another factor is that the policies taken by the relevant parties in addressing the issue of law enforcement are still partial, patchy, not comprehensive, and systematized. Criminal law enforcement is required in a progressive legal paradigm. So far law enforcement has focused on the dimensions of the form that make it formal and procedural. There is a difference between formal justice and substantial justice. The law is often used to pervert substantial justice. Thinking progressively means daring to get out of the mainstream of legal absolutism, then putting the law in a relative position that is put in the whole humanitarian issue. If progressive law is used as a paradigm by law enforcement in Indonesia, then the principle of ultimum remidum will be very easy to apply.

\section{ACKNOWLEDGEMENTS}

The author would like to thank the Faculty of Law Universitas Pancasakti Tegal for providing funding for this research in 2020. All authors contributed to this research according to their respective assignments.

\section{REFERENCES}

Adji, E. A. (2011). Pergeseran Paradigma Pemidanaan [Criminal Conviction Paradigm Shifts]. Bandung: Lubuk Agung.

Anindyajati, T. et al. (2016). "Konstitusionalitas Norma Sanksi Pidana sebagai Ultimum remedium dalam Pembentukan Perundangundangan [Norm Constitutionality of Criminal Sanctions as Ultimum remedium in the formation of Legislation]". Jurnal Konstitusi. 12, (4), 872-892. https://doi.org/10.31078/jk12410

Ansori, L. (2018). "Reformasi Penegakan Hukum Perspektif Hukum Progresif [Law Enforcement Reformation: Progressive Law Perspectives]". Jurnal Yuridis. 4, (2), 148-163. https://doi.org/10.35586/.v4i2.244

Anwar, M., \& M.R. Wijaya. (2020). "Fungsionalisasi dan Implikasi Asas Kepentingan Terbaik Bagi Anak yang Berkonflik dengan Hukum: Studi Putusan Pengadilan Tinggi Tanjung Karang [Functionalization and Implication of Best Interest Principle for Children having Conflicts with Law]". Undang: Jurnal Hukum. (2), 265-292.

https://doi.org/10.22437/ujh.2.2.265-292

Arief, B. N. (2005). Teori-Teori dan Kebijakan Pidana [Criminal Theories and Policies]. Bandung: Alumni.

Ariyanti, V. (2019). "Kebijakan Penegakan Hukum dalam Sistem Peradilan Pidana Indonesia [Law Enforcement Policies in Indonesian Criminal Justice System]". Jurnal Yuridis. 6 (2), 33-54. https://doi.org/10.35586/jyur.v6i2.789

Arliman, L. (2019). "Mewujudkan Penegakan Hukum yang Baik di Negara Hukum Indonesia [Realizing Good Law Enforcement in the State of Law of Indonesia]". Dialogia Iuridica. 11, (1), $1-20$. https://doi.org/10.28932/di.v11i1.1831

Azisa, A. S. (2016). Hukum Pidana [Criminal Law], (Kadarudin (ed.). Makassar: Pena Press.

Basuki, M. (2018). "The Implementation of Ultimum remedium Principles in Law Enforcement of Criminal Act Illegal Mining", Proceedings of the 2018 International Conference on Energy and Mining Law (ICEML 2018), 59, (4), 51-55. https://doi.org/10.2991/iceml-18.2018.13

Darwis, R. (2003). Pendidikan Hukum dalam Konteks Sosial Budaya bagi Pembinaan Kesadaran Hukum Warga Negara [Law Education in social-cultural Context to Supervise the Citizens' Law Awareness]. Bandung: Departemen Pendidikan Indonesia Universitas Pendidikan Indonesia.

Dewi, E. (2014). "Penegakan Hukum Terhadap Pelaku Tindak Pidana Pemalsuan Uang Dan Pengedar Uang Palsu di Kota 
Bandar Lampung [Law Enforcement to the actors counterfaiting and circulating the conterfait money in Bandar lampung City]", Keadilan Progresif. 5 (1), 71-87.

Efendi, S. D. J. (2010). Panduan Praktis Bila Menghadapi Perkara Pidana, Mulai Proses Penyelidikan Sampai Persidangan [Practical Guidance when Facing Criminal cases starting from Investigation to Trial]. Jakarta: Prestasi Pustaka.

Firdaus, A., et al. (2020). "Environmental Criminal Responsibility for Mining Corporation Through the Ultimum remedium Principle". Advances in Social Science, Education and Humanities Research, 413 (1st International Conference on Law, Governance and Islamic Society (Icolgis)), 48-50. https://doi.org/10.2991/assehr.k.200306.179

Fletcher, G. P. (1998). "The Nature and Function of Criminal Law". California Law Review, 88, (3), 1-20. https://doi.org/10.2307/3481188

Hamzani, A.I., F. D. Aryani, H. Aravik. 2020. "The Trend to Counter Terrorism in ASEAN". Journal of Advanced Research in Dynamical and Control Systems, 12, (7), 105-113. https://doi.org/10.5373/JARDCS/V1217/20201990

Husak, D. (2014). "The Criminal Law as Last Resort". Oxford Journal of Legal Studies, 24, (2), 207-235. https://doi.org/10.1093/ojls/24.2.207

Imron, A. (2016). "Peran dan Kedudukan Empat Pilar dalam Penegakan Hukum Hakim Jaksa Polisi Serta Advocat Dihubungkan Dengan Penegakan Hukum Pada Kasus Korupsi [Role and Position of Four Pillars in the Law Enforment made by the Judges, Prosecutors, Police, and Lawyers Related to the Law Enforcement in the Corruption Cases]". Jurnal Surya Kencana Satu: Dinamika Masalah Hukum Dan Keadilan. 6 (1), 83-107. https://doi.org/10.32493/jdmhkdmhk.v6i1.340

Indrawati, B. M. (2018). "Penerapan Asas Ultimum Remidium Dalam Penegakan Hukum Pidana di Bidang Cukai [The Implementation of Ultimum Remidium in the Criminal Law Enforcement in the Field of Excise Duty]". Jurnal Cakrawala Hukum. 9, (1), 11-20.

https://doi.org/10.26905/idjch.v9i1.2118

Jainah, Z. O. (2011). "Membangun Budaya Hukum Masyarakat Penegak Hukum Dalam Pemberantasan Tindak Pidana Narkotika [Building the Law Enforcers' Public Law Culture in Eradicating the Drug-related Crimes]". Jurnal Keadilan Progresif. 2, (2), 123-136. http://jurnal.ubl.ac.id/index.php/ KP/article/view/82

Januarsyah, M. P. Z. (2017). "Penerapan Prinsip Ultimum remedium dalam Tindak Pidana Korupsi Kajian Putusan Nomor 2149 K/Pid.Sus/2011 [The Implementation of Itimum Remedium Principles in Corruption Crimes: A Study on Decision No. 2149 K/Pid.Sus/2011]". Jurnal Yudisial. 10, (3), 257-276. https://doi.org/10.29123/jy.v10i3.266

Julaiddin. (2018). "Penegakan Hukum yang Tidak Bersesuaian dengan Ketentuan Hukum Pidana dalam Proses Penyelidikan dan Penyidikan Yang Menyebabkan Timbulnya Korban (Dalam Kajian IImu Viktimologi)". UNES Journal of Swara Justisia, 2 (1), 74-88. https://doi.org/10.31227/osf.io/m6agi

Kartanto, L., P. Rijadi \& S. Priyati. (2020). "Quo Vadis Ultimum remedium in Tax Criminal Crimes In Indonesia". International Journal of Scientific and Research Publications (IJSRP), 10, (3), 1-13.

https://doi.org/10.29322/IJSRP.10.03.2020.p9902

Faizal, L. (2007). "Perilaku Penegak Hukum menuju Penegakan Hukum Progresif dalam Persfektif Pembangunan Hukum Nasional [Law Enforcement Behaviors Leading to the Progressive Law Enforcement in the Perspective of National Law Development]". Asas: Jurnal Hukum dan Ekonomi Islam. 4, (1), 1-9. https://doi.org/10.24042/asas.v4i1.1666

Nugraha, M.S.W., \& S. Putrawan. (2018). "Pemberian Sanksi Pidana Sebagai Ultimum remedium Dalam Undang-Undang
Perlindungan dan Pengelolaan Lingkungan Hidup [Imposing Criminal Sanctions as Ultimum remedium in the Law of Environmental Protection and Management]". Kertha Wicara: Journal IImu Hukum. 7 (2), 1-11. https://ojs.unud.ac.id/index.php/kerthawicara/article/view/386 61

Mahrus, A. (2007). "Sistem Peradilan Pidana Progresif: Alternatif dalam Penegakan Hukum Pidana". Jurnal Hukum lus Quia lustum. 14 (2), 210-229.

https://doi.org/10.20885/iustum.vol14.iss2.art2

Marilang. (2017). "Menimbang Paradigma Keadilan Hukum Progresif [Considering the Progressive Law Justice Paradigm]". Jurnal Konstitusi. 14, (2), 315-331. https://doi.org/10.31078/jk1424

Mertokusumo, S. (2006). Penemuan Hukum Sebuah Pengantar [Law Finding: An Introduction]. Yogyakarta: Liberty.

Notohamidjojo, O. (2011). Soal-Soal Pokok Filsafat Hukum [Main Questions of Law Philoshopy]. Sakatiga: Griya Media.

Prasetyo, T. (2010). Hukum Pidana [Criminal Law]. Jakarta: Rajawali Press.

Priyono, et al., (2019). "Penegakkan Hukum Sanksi Pidana Perpajakan Berdasarkan Undang-Undang Nomor 16 Tahun 2019 Tentang Ketentuan Umum dan Tata Cara Perpapajakan Dikaitkan dengan Asas Ultimum remedium [Law Enforcement of Taxation Criminal Sanctions based on Law No. 16 Year 2019 on General Provision and Taxation Management related to the Ultimum remedium Principles]". Wacana Paramarta: Jurnal Ilmu Hukum, 18, (1), 1-14. https://doi.org/10.32816/paramarta.v18i1.62

Prodjodikoro, W. (2003). Asas-Asas Hukum Pidana Di Indonesia [Criminal Law Principles in Indonesia]. Bandung: PT. Refika Aditama.

Rahardjo, S. (2007). Membedah Hukum Progresif [Revealing Progressive Law]. Jakarta: Kompas.

Rahmawati, N. A. (2013). Hukum Pidana Indonesia: Ultimum remedium Atau Primum remedium [Indonesian Criminal Law: Ultimum remedium or Primum remedium]. Recidive, 2(1), 39-44.

Subyakto, K. (2015). "Azas Ultimum Remedium ataukah Azas Primum remedium yang Dianut dalam Penegakan Hukum Pidana pada Tindak Pidana Lingkungan Hidup pada UU Nomor 32 Tahun 2009 tentang Perlindungan dan Pengelolaan Lingkungan Hidup [The Principle of Ultimum remedium or Primum remedium Adopted in the Criminal Law Enforcement in the Environmental Crimes based on Law No. 32 Year 2009 on Environmental Protection and Management of ]". Jurnal Pembaharuan Hukum, 2, (2), 209-213.

Suhardin, Y. (2009). "Fenomena Mengabaikan Keadilan dalam Penegakan Hukum [Justice Neglection Phenomena in Law Enforcement]". Mimbar Hukum, 21, (2), 203-408. https://doi.org/10.22146/jmh.16261

Sunardi, et al., (2005). Republik "Kaum Tikus"; Refleksi Ketidakberdayaan Hukum Dan Penegakan Ham [The "Rat Group" Republic: Helplessness Reflection of law and the Enforcement of Human Rights ]. Jakarta: Edsa Mahkota.

Vollaard, B. (2013). "Preventing Crime Through Selective Incapacitation". Economic Journal, 123, (567), 262-284. https://doi.org/10.1111/j.1468-0297.2012.02522.x

Wantu, F. M. (2012). "Mewujudkan Kepastian Hukum, Keadilan dan Kemanfaatan dalam Putusan Hakim di Peradilan Perdata [Realizing the Certainty of Law, Justice, and Utilization within the Decisions of Judges in Criminal Courts]". Jurnal Dinamika Hukum. 12 (3), 479-490. https://doi.org/10.20884/1.jdh.2012.12.3.121

Wisnubroto, P. et al., (2017). "Urgensi Perubahan Paradigma Penegakan Hukum Dalam Menghadapi Tantangan Era Kontemporer [The Urgency of Law Enforcement Paradigm Changes in Facing the Contemporary Era Challenges]". Justitia Et Pax Jurnal Hukum. 33, (1), 1-16. https://doi.org/10.24002/jep.v33i1.1415 
Yadyn, et al. (2010). Problematika Penegakan Hukum di Indonesia Menuju Hukum Yang Responsif Berlandaskan Nilai-Nilai Pancasila [Law Enforcement Problems in Indonesia Leading to the Responsive Law based on the Indonesian Five Basic Principles]. Makassar: Universitas Hasanuddin.

Yoserwan, et al. (2019). "The Implementation of Ultimum remedium Principle in Economic Criminal Law of Indonesia". Journal of Legal, Ethical and Regulatory Issues, 22, (2), 1-5. https://www.abacademies.org/articles/The-implementation-ofultimum-remedium-principle-in-economic-criminal-law-ofIndonesia-1544-0044-22-2-314.pdf
Zahra, A. \& R.B. Sularto. (2017). "Penerapan Asas Ultimum remedium Terhadap Anak Pelaku Tindak Pidana Narkotika [The Implementation of Ultimum Remedium Principles to Children committing the Drug-related Crimes]". Jurnal Law Reform. 13, (1), 18-27. https://doi.org/10.14710//r.v13i1.15948

Zaidan, M. A. (2014). "Norma, Sanksi dan Teori Pidana Indonesia [Criminal Norms, Sanctions, and Theories ]". Jurnal Yuridis. 1 (1), 107-124.

Zaidan, M. A. (2015). Menuju Pembaharuan Hukum Pidana [Leading to the Renewal of Criminal Law ]. Jakarta: Sinar Grafika.

Received on 10-03-2021

Accepted on 03-05-2021

Published on 11-05-2021

https://doi.org/10.6000/1929-4409.2021.10.119

(C) 2021 Abdurrachman et al.; Licensee Lifescience Global.

This is an open access article licensed under the terms of the Creative Commons Attribution Non-Commercial License (http://creativecommons.org/licenses/by-nc/3.0/) which permits unrestricted, non-commercial use, distribution and reproduction in any medium, provided the work is properly cited. 